\title{
Correction to: Assessing the impacts of cell wall composition on the optimum stage for "Uradome" in moso bamboo
}

Yuka Furusawa ${ }^{1,2^{*}}$ and Tatsuya Ashitani $i^{1,3}$

\section{Correction to: J Wood Sci (2021) 67:38}

https://doi.org/10.1186/s10086-021-01971-x

After online publication of the article [1], an error was found in Fig. 3. The change does not affect the conclusions of the article in any way. The corrected Fig. 3 is given in this erratum:

${ }^{1}$ The United Graduate School of Agricultural Sciences, Iwate University,

3-18 Ueda, Morioka, Iwate 020-0066, Japan

Full list of author information is available at the end of the article 


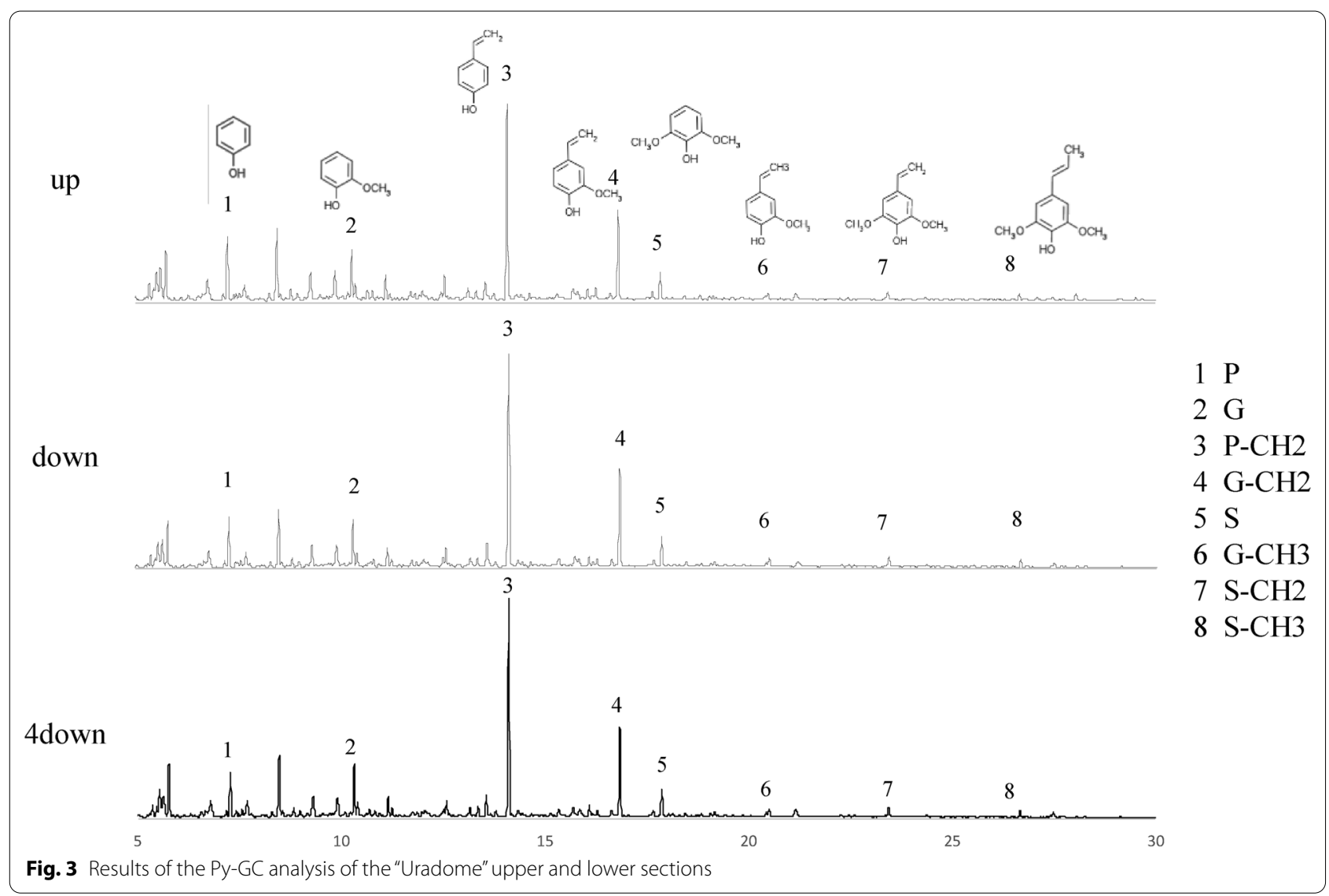

\section{Author details}

${ }^{1}$ The United Graduate School of Agricultural Sciences, Iwate University, 3-18 Ueda, Morioka, Iwate 020-0066, Japan. ${ }^{2}$ Yamagata Prefectural Forest Research and Instruction Center, 2707 Hei Sagae, Sagae, Yamagata 991-0041, Japan. ${ }^{3}$ Faculty of Agriculture, Yamagata University, 1-23 Wakabamachi, Tsuruoka, Yamagata 997-0037, Japan.

Published online: 02 August 2021

\section{Reference}

1. Furusawa Y, Ashitani T (2021) Assessing the impacts of cell wall composition on the optimum stage for "Uradome" in moso bamboo. J Wood Sci 67:38. https://doi.org/10.1186/s10086-021-01971-x

\section{Publisher's Note}

Springer Nature remains neutral with regard to jurisdictional claims in published maps and institutional affiliations.

\section{Submit your manuscript to a SpringerOpen ${ }^{\odot}$ journal and benefit from:}

- Convenient online submission

- Rigorous peer review

- Open access: articles freely available online

- High visibility within the field

- Retaining the copyright to your article

Submit your next manuscript at $\mathbf{s p r i n g e r o p e n . c o m ~}$ 